\title{
The rank of capacity of people at Karo district in encountering volcano disaster
}

\author{
Lismawaty ${ }^{1, *}$, Rahmadian Sembiring ${ }^{2}$, and Dessy Eresina Pinem $^{2}$, \\ ${ }^{1}$ Medan Institute of Technology, Geology Engineering Department, Gedung Arca Street No 52, Medan, Indonesia \\ ${ }^{2}$ Medan Institute of Technology, Regional and City Planning Department, Gedung Arca Street No 52, Medan,Indonesia
}

\begin{abstract}
It had been more than 400 hundred years since Mount Sinabung last eruption. Hence, people have built settlements at its slope. However, in 2010, the mount began to erupt and consequently more than 10.000 ha farmland damaged and more than 28.000 people evacuated. Until now, it has been 7 years since the eruption and no one knows when it stops. Who will help the community when disaster strikes? Based on experience, the fastest aid always comes from the adjacent community. Therefore, the first helper, which are expected, is from the adjacent community or from the victims themselves. This research aims to find the level of capacity of victims of Mt. Sinabung disaster in encountering the disaster at every process of disaster management. This research is a qualitative descriptive research. The data obtained from interviews and focus discussion group (FGD). Interview conducted to get what the community has been done at every phase of management. This study found that rank of the capacity of villagers at every phase of disaster management in general is very low. They only reach the phase of understanding, but not motivated or search much information about prevention, mitigation and response.
\end{abstract}

\section{Introduction}

Karo district has 2 active volcanoes named Mount of Sinabung and mount of Sibayak. Sinabung is the most active Mountain among another mountain of The Giant Mount Toba. It has been more than 400 hundred years that the mountain of Sinabung stays calmed, therefore, people have built the settlements at its slope. However, in 2010, the mount began to erupt and consequently, more than 10.000 ha husbandry damage and more than 28.000 people should be evacuated. Until now, it has been 7 years eruption and no one knows when it stops.

This explosion warned the people near Sinabung (people of Karo district) that they live at the disaster zone, therefore they should be prepared and trained in encountering the disaster and has a management system to overcome the disaster.

When a disaster happens, the victims must be people around the disaster. Who is expected to help at the time after a disaster just happened? Can we expect rescuer from outside district? Humanity aids for disaster victims usually come late or wrongly targeted. Based on experience, the fastest aid usually come from the adjacent community, so, the first helpers to be expected are from the adjacent community or from the victims themselves. Thereupon, people who live in the disaster region should be well trained to face the emergency situation, well prepared, have a duty allocation, can do the first aid, can prepare evacuation place, etc. This research aims to find the level of capacity of the victim of Mt. Sinabung disaster to face the disaster in every process of disaster management.

\section{Material and method}

Disaster management is every attempt or activity to keep out a disaster, mitigation, make a readiness and restoration in relation to the disaster which is done before, at the time and after a disaster. In disaster management, there are some activities, pre-disaster, at the time of disaster and after the disaster, such as prevention, mitigation, preparedness, early warning, response, relief, recovery, rehabilitation, and reconstruction.

Robinson (1994) quote from Ismail (2016) as in [1] said that empowerment is a personal and social process; a deliverance of personal ability, competence, creativity and freedom to act. Ife (1995) quote from Ismail (2016) as in [1] said that empowerment relates to give potency, give strength, and give power, to those who lack power.

Slamet (2003) quote from Nawalah (2012) as in [2] describes more details that community with capacity is a community who knows, understands, motivated, can use the opportunity, full of energy, cooperative, knows many alternatives, able to decide, brave to take risk, able to search and get information and able to take action according to situation. Empowerment process with those criteria should be done continuously and ask the participation of community optimally.

Corresponding author: $\underline{\text { liz_geoitm@yahoo.com }}$ 


\subsection{Community empowerment in disaster management}

Regarding disaster management, according to Law no $24 / 2007$, the participation of people is very being concerned. The people not only be the victims or objects, but they are the actors to countermeasures the disaster.

Activities to countermeasures a disaster based on people are:

1. To increase the community's ability and comprehension.

2. To increase the community's ability to identify problems and plan the solution, etc.

Community's roles to countermeasures a disaster are:

1. To reduce disaster risk by saving the environment

\subsection{Methodology}

This research is a qualitative descriptive research. The data obtained from the interviews and focus discussion group (FGD). Interviews were conducted to get information on what the community has been done at every phase of management: prevention, mitigation, preparedness, early warning, response, relief, recovery, rehabilitation, and reconstruction.
2. To actively make programs to countermeasures the disaster

3. To join the disaster simulation

4. Make countermeasures a disaster (correspond to local genius).

The role of community organization in counter measuring a disaster are:

1. Get involved actively in making curriculum of disaster preparedness of the community

2. Be with the community to design programs to countermeasures the disaster.

3. Create disaster training/simulation for community

4. Do some socialization and education for the community.

FGD is a process of collecting specific information by group discussion (Irwanto,1998) quote from Rivai (2016) as in [3]. Henning dan Columbia (1990) quote from Rivai (2016) as in [3] said that FGD is interview on a small group of people that conducted by an informant who pushes the community to speak up freely about anything important related to the topic of discussion.

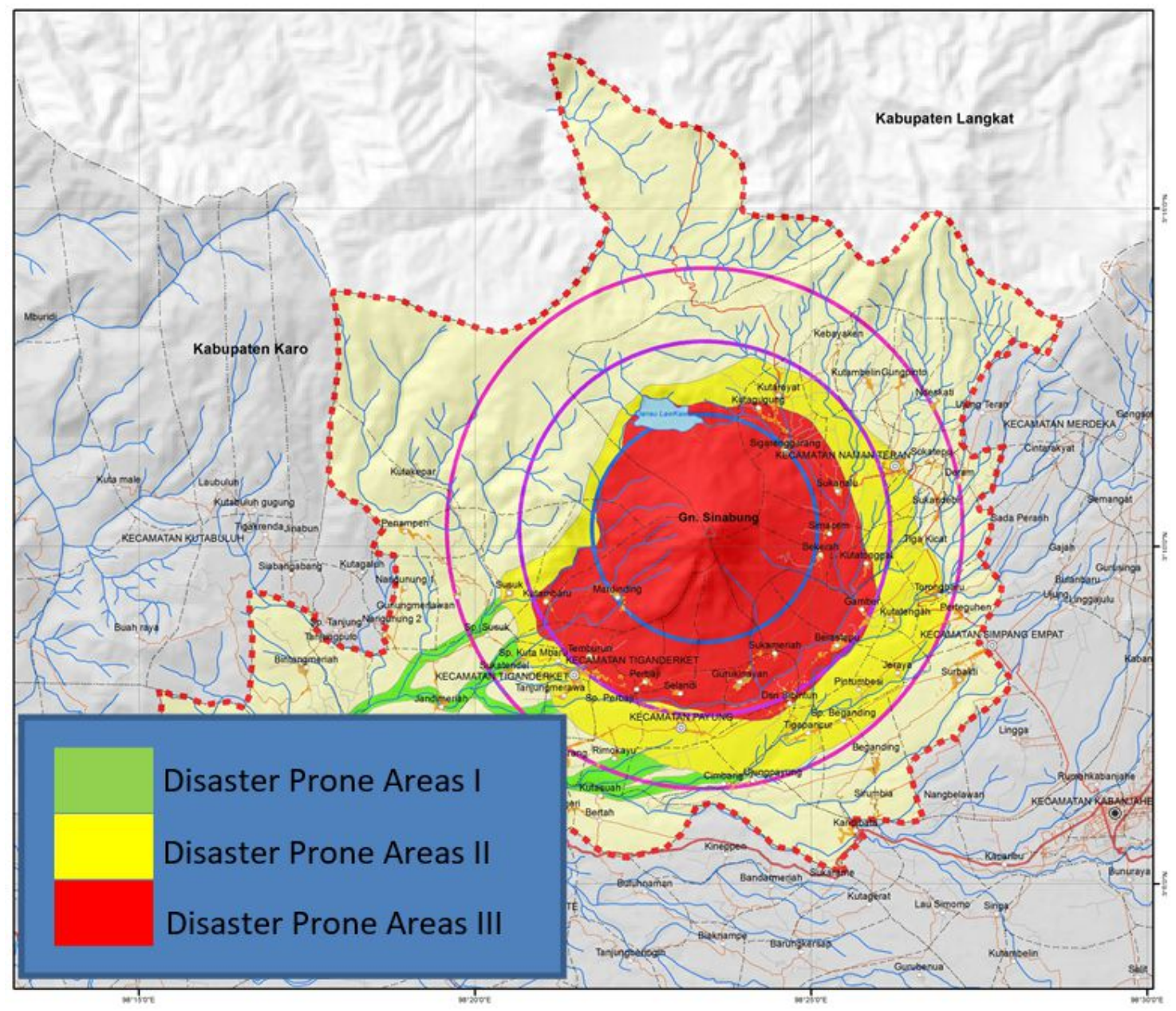

Fig. 1. Map of Disaster Risk and Location of Villages 
Variables used in this research are: the action of the community at every phase of management: prevention, mitigation, preparedness, early warning, response, relief, recovery, rehabilitation, and reconstruction and allocate their action to 8 classes of form capacity such as:

1. Communities know

2. Communities understand

3. Communities are motivated

4. Communities know many alternatives of prevention and other phases of disaster management

5. Communities able to make a decision in every phase of disaster management

6. Communities are brave to take a risk

7. Communities able to search and get information about prevention and other phases

8. Communities able to take action based upon the situation.

The respondents chose by purposive sampling method. They are leaders from the community such as the chief of villages, elders, head of youngsters organization, head of refugees points, etc. The respondents are about 20 persons from one village.

\subsection{The location of research}

The location of research is in the villages which affected by the eruption of Sinabung. The villages are Sukanalu, Pintu Besi, Sigarang-Garang, and Kuta Tengah. The location of those villages can be seen in picture 2 as in [4]. People of the villages still recorded as refugees because the village is in disaster zone 2 and 3. For more information, look at the table below and see picture 1 .

Tabel 1. Location of villages surveyed in reference of disaster risk map

\begin{tabular}{|r|l|c|}
\hline No & \multicolumn{1}{|c|}{ Villages } & $\begin{array}{c}\text { Rank of } \\
\text { Disaster } \\
\text { Risk }\end{array}$ \\
\hline 1 & Desa Sukanalu & III \\
\hline 2 & Desa Pintu Besi & II \\
\hline 3 & Desa Sigarang-garang & III \\
\hline 4 & Desa Kuta Tengah & II \\
\hline
\end{tabular}

Reference [4] shows that most of the land use around $5 \mathrm{~km}$ near Sinabung is agriculture. See picture 2.

\section{Result and discussion}

Although people of Sigarang-Garang, Sukanalu, Pintu Besi and Kuta Tengah should not back to their village, they disobeying it because they have to earn money for living. The government only gives money for daily food and school fee until junior high school (Sekolah Menengah Tingkat Pertama). Some of them create new farmland and forest near Jahe street, some of them work at Kabanjahe and many of them back to their village and still plant at their farm although it is a red zone (forbidden zone).

\subsection{Disaster preparation and mitigation}

A training for facing disaster ever been done at 2010 (at the village of Sigarang-Garang), 2013 ( at the village of Sukanalu), 2015 (at the village of Pintu Besi and Kuta Tengah). But not all the refugees joined the training. They said that the training is only done once. At that training, they got a lesson about what should they do to protect themselves when an earthquake happens, what to bring to evacuate, etc. But they did not get the lesson about first aid so if there are victims, they don't know what to do except bring the victims to the nearest hospital. In the Village of Kuta Tengah, they said that they ever trained how to save the elders using litter, and create a meeting point. But the training is not repetitively.

According to them, they are never trained to make evacuation route, vulnerability map, capacity map, and disaster risk map. There is disaster risk map that launched by the government and they use it so they know where the position of their village is, whether it is at first disaster zone or second disaster zone or third.

\subsection{Early warning system}

In the year 2010, each village had given 1 handy talkie for communication tools. Now it has been broken. At that time, the villagers turned to HT (handy talky). The holder of HT will be connected soon to mountain observer (government) if the emergency situation was coming. In addition, the holder of HT should soon give the announcement to villagers by portable loudspeaker.

The villagers evacuated by their own vehicle. But after the big eruption in 2013, the government pushed them to leave village so that now there is no early warning there. But, there still a few villagers live at Desa Sigarang-Garang, Sukanalu, Pintu Besi and Kuta Tengah. If the refugee villagers get information about the emergency situation, they will call, by cellular phone, their families who still live at the village to warn and evacuate.

Differences found at people of Pintu Besi. They still have 11 Handy Talkies (HT) until now. They purchased those from the village fund. The HT held by eleven chosen villagers who will get informed about the emergency situation from mountain observer (government) and they have a duty to give warning to their family who still lives at the village by cellular phone. However, there is no standard operating procedure or mechanism to state who will call who.

Most of the villagers have a cellular phone and the cellular signal is strong even in the middle of farmland. Their HT can observe seismic so HT will give them warning if the seismic is ascending. These facts are not found at 3 others village. 


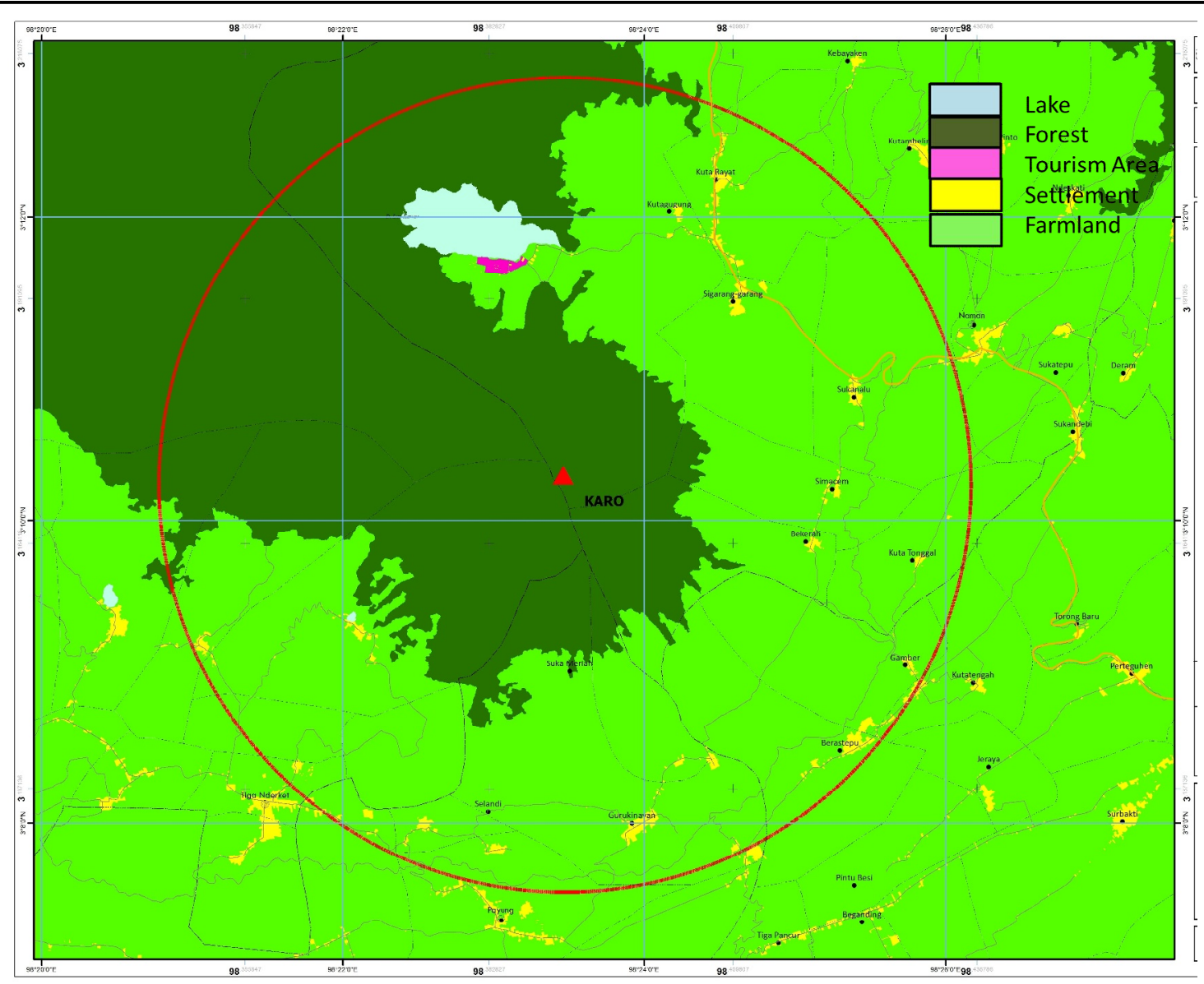

Fig. 2. Map of land use around $5 \mathrm{~km}$ from peak of Sinabung

\subsection{Evacuation}

People of Sigarang-Garang, Sukanalu, Pintu Besi and Kuta Tengah know that lava or hot cloud, ash and big rock will come to their villages but they have accustomed to it. They prepare themselves by own vehicles like motorcycle and car. Some of them have organized themselves for example, who will pick their families and relatives or which car to evacuate. Some of them have bought a car together as a vehicle to evacuate their family together. But the decision to run or evacuate depends on their self-decision (no instruction or command from a leader). There is no coordination. Sometimes, when a very bad emergency happened, the government will pick them up with a truck but soon when the situation is getting stable, they are back one by one.

They have parked their motorcycle's head to the evacuation route. They found their evacuation route themselves (not by training) after the eruption in 2010 . They searched a save street to avoid the mountain. Some of them run to Kabanjahe and many others run to Langkat District.

Except at Village of Pintu Besi, they said that there is an evacuation route made by the government with the signs of way and point of temporary evacuate place. However, there is no special vehicle ready to evacuate prepared by the government.
Also in Kuta Tengah, there were several meeting points. One meeting point was Balai Desa which has a parking lot of vehicles to refugees point. But now Kuta

Tengah has been abandoned by villagers. There are only about 30 persons there.

Most of the villagers know the way to evacuate them, including villagers who always spend their day in the middle of the agriculture field.

\subsection{Response}

The affected villager depend on volunteers who in charge to help them. The volunteers do not come from their village. The villagers do not know who paid the volunteers. Some of their youngsters from their own villages asked to be volunteers (professional) but no one wants. The volunteers are not many but when a disaster happened, they call their friends and many other volunteers come to help.

Their 'new' village (near Jahe street) has many youngsters and elders. There is a youth organization named Karang Taruna. There are also churches there. But, In Karang Taruna, there are no duty allocations or assignments if a disaster happens or to prepare before a disaster such as who prepare vehicles, who will take care of the elders, who observing mountain, who give warning, etc. They observe the mountain one by one spontaneously (no duty allocation). They also listen to the radio who will give a warning if an emergency situation coming. And the decision to evacuate depends 
on their selves (there is no command from a leader). At refuges point in Kabanjahe, duty allocation (especially on the emergency situation) is only done by volunteers, not the villagers.

\subsection{Relief}

The sanitation at refuges points in Kabanjahe is good. There is water from wells and there are enough toilets. The refugees cook food and it is distributed by Regional Disaster Management (Badan Penanggulangan Bencana Daerah or BPBD) Karo. For health services, there are medical tents for refugees and they can checked by a doctor at the hospital if it is needed by using a recommendation from volunteers.

\subsection{Recovery, rehabilitation, and reconstruction}

The Solution for Sigarang-Garang, Kuta Tengah, Pintu Besi and Sukanalu are the refugees will get new houses and farmlands or they search their own land and government pay for it. The villagers agree to get a new location for their village. For now, they are still waiting for new location. There are few villagers reconstruct their house by themselves at 'old' village while waiting for the relocation.

\subsection{Local genius}

Now they can predict the situation of Sinabung. They always see the mountain and can distinguish the hot cloud or cold cloud. If the cloud is grey and run down, it is hot cloud and they evacuate soon. But if the cloud is white and moves up, they choose to stay. If there is an earthquake, they will wait until the earthquake gets hard to evacuate. One of the sign is sound of thunder from Sinabung. Usually, Sinabung makes a thunder sound before erupting. They know that they have to live together harmoniously with this active mountain and get used to it.

According to them, if heavy rain comes, soon (in 1 hour) it will come the eruption. If the weather so hot until about $33{ }^{\circ} \mathrm{C}$ (normal hottest temperature is about $27^{\circ} \mathrm{C}$ ) the eruption will also happen. They also can predict the way of wind and the distance of ash according to the height of cloud erupted by Sinabung.

They push themselves to plant broccoli, cabbage, and coffee. The cabbage has the time to harvest, but did not get many as usual. And according to them, coffee is suitable to grow on the volcanic land.

\subsection{The rank of capacity of villagers}

Rank of capacity only mentioned at phase: prevention, mitigation, preparedness, early warning, response, and relief. The phase of recovery, rehabilitation, and reconstruction can't be described because all villages do not do those phases because they are still waiting for relocation.

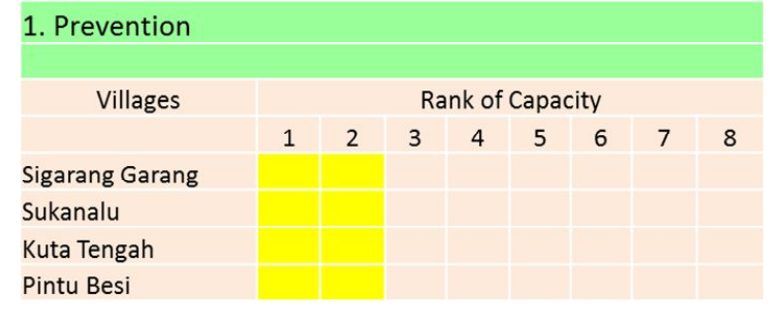

Fig. 3a. The rank of capacity at prevention phase

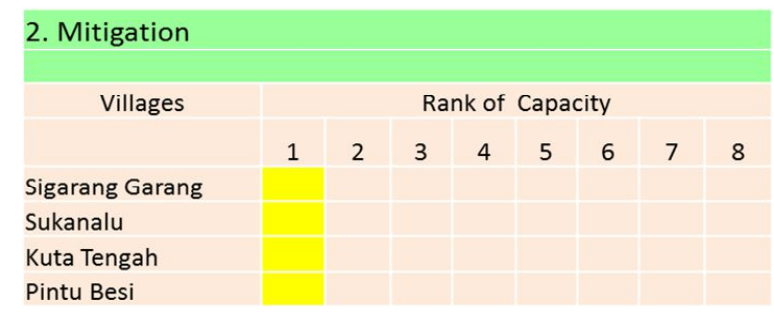

Fig. 3b. The rank of capacity at mitigation phase

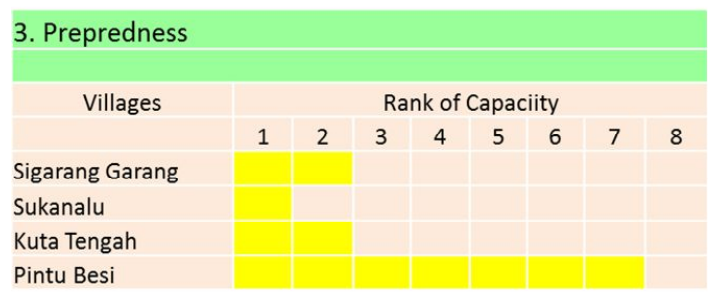

Fig. 3c. The rank of capacity at preparedness phase

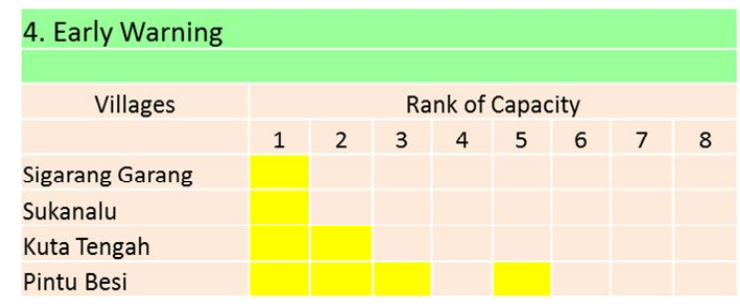

Fig. 3d. The rank of capacity at early warning phase

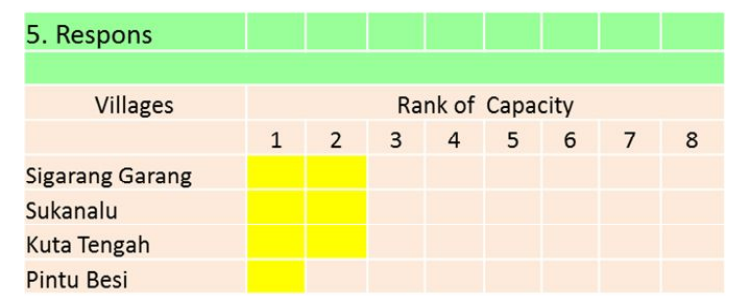

Fig. 3e. The rank of capacity at respons phase

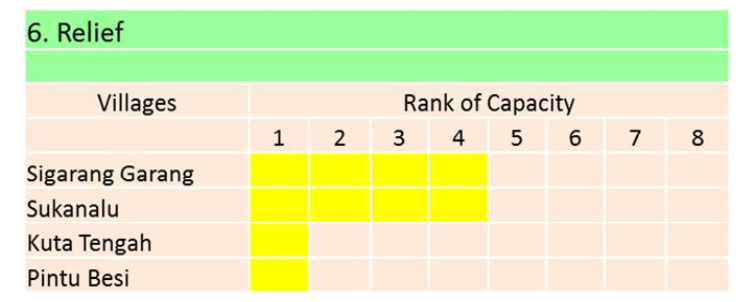

Fig. 3f. The rank of capacity at relief phase

Rank Reached 
Note:

There are 8 ranks of capacity:

1. Communities know

2. Communities understand

3. Communities are motivated

4. Communities know many alternatives of (every phase of disaster management)

5. Communities able to make a decision in (every phase of disaster management)

6. Communities are brave to take a risk

7. Communities able to search and get information (at every phase of disaster management)

8. Communities able to take action based upon the situation.

\section{Conclusion}

This study found that:

1. Rank of a capacity of villagers at every phase of disaster management in common is very low. At the phase of prevention, mitigation, response, they only reach the second rank of capacity that means they only reach the phase of understanding, but not motivated or search much information about prevention, mitigation and response. Except at Pintu Besi Village, they got rank 7 and 5 at preparedness and early warning phase where they able to search and get information about preparedness and early warning. They have 11 Handy Talkie to spread the information or warning fast.

2. Sigarang-Garang and Sukanalu villagers get 4 ranks at relief because they have made their new village and agricultural field near Jahe Street to earn money whether it is on legal land or illegal.

3. At the response phase, all the villagers get rank 1 or 2 because many things have been done such as distributing blanket, distributing emergency food, making a list of refugees, etc, but these actions were taken by volunteers, which are people from outside their village, not the villagers.

4. At the phase of early warning all communities do not organize them to help each other, make a system of spreading information, etc. The spreading of information only based on instinct to save family and relatives.

5. At the phase of a response, the villagers have made a evacuation plan, such as who will get into whose car and the way to evacuate. This plan made by the big family such as son, daughter, mother in law, grandson, etc. For a family who can afford to buy a car, they buy a car for a vehicle to evacuate. Moreover, sometimes they buy a car together for their vehicle to evacuate. But there is no plan of the whole village (only for big family).

6. At the phase of the response, every person has had their own plan to evacuate. Especially those who always spend their time in the agriculture field which is far from other people. At the time they get a warning (by phone or by watching the mountain), they have had a plan where to run. Also for mother and children who stay at the village (not in the agriculture field), they have had plan where to run and ride whose vehicle.

7. Some local genius emerged:

a. Plants that persist of ash are cabbage (from Sukanalu villagers) and coffee (from Kuta Tengah villagers. But their products are very low.

b. They can predict whether it is a cloud or only ash from the way of down and color of the cloud.

c. By seeing the height of cloud erupted by Sinabung, they can predict how long the volcanic ash will go.

8. For more than 7 years of eruption, there are only a few numbers of non-governmental organizations that want to involve to manage the people. There are many organizations in the village such as Karang Taruna and Church Youngsters but they do not create a disaster management like responsibility division in disaster management, distributing information, disaster preparation training, etc. Example of non-governmental organization which helps and manage refugee is KNPI.

9. For 7 years eruption, people or refugee don't want to know about managing their selves in facing the disaster. No institutional organizations are built, no system of information distribution, or evacuation procedure. The system of distribution only by warning family (but no list and division) by cellular phone.

10. The evacuation procedures do not exist. They decide, by themselves, the time to evacuate if a disaster happens. Their decisions only according their own courage.

11. At the phase of preparedness, there is no attention to prepare themselves about how to response the disaster by training regularly. They got training about how to react at the time of disaster but not regularly and only 1 or 2 times for this 7 years continuing disaster.

\section{References}

1. F. Ismail, S. Akhmad Nurhakim, H. Rachim, Prosiding KS: Riset dan PKM Vol 3 No 1 (2016)

2. H. Nawala, B. Qomaruddin, R. Hargono., IJPH Vol 8 No 3 (2012)

3. A. Rivai, JK Vol 1 no 1( 2016)

4. D. Megana Silalahi. Thesis of S1 Pendidikan Geografi, UNIMED (2014) 